GRASAS Y ACEITES 69 (2)

April-June 2018, e252

ISSN-L: 0017-3495

https://doi.org/10.3989/gya.1113172

\title{
Phytochemical profile and antioxidant capacity of virgin olive oil obtained from the olive cultivar 'Roghiani' from different regions of northern Libya
}

\author{
S.M. Esalami ${ }^{\mathrm{a}, \bowtie}$, E.B. Dimic ${ }^{\mathrm{a}}$ and B.B. Rabrenovic ${ }^{\mathrm{b}}$ \\ ${ }^{a}$ University of Novi Sad, Faculty of Technology, Bulevar Cara Lazara 1, 21000 Novi Sad, Serbia \\ ${ }^{b}$ University of Belgrade, Faculty of Agricultural, Zemun, 11000 Belgrade, Serbia \\ Corresponding author: Seddiq20092000@yahoo.com
}

Submitted: 21 November 2017; Accepted: 16 February 2018

SUMMARY: The aim of this work was to determine the fatty acids (FA), tocopherols, phenols, and antioxidant capacity (AC) of five virgin olive oils (VOO) obtained from the olive cultivar 'Roghiani', from different regions of northern Libya during the crop year 2015. The parameters determined for the oils were investigated for the first time. Seven principal FAs were detected in the VOO samples. Oleic, palmitic, and linoleic acids were the dominant ones. The highest percentage of palmitic acid was found in Tripoli VOO $(P \leq 0.05)$. Oleic acid was dominant in all the VOO samples. Gharyan VOO possessed the highest value of oleic acid, O/L ratio, monounsaturated fatty acids (MUFA), total phenols content (TPC), total tocopherol and tocotrienol contents (TTC), and $\mathrm{AC}^{\mathrm{DPPH}} \%(P \leq 0.05)$. A strong positive relationship between TPC and $(\mathrm{AC})$ as $\left(1 / \mathrm{EC}_{50}{ }^{\mathrm{DPPH}}\right)$ was observed, (r) was +0.831 . On the other hand, $\left(1 / \mathrm{EC}_{50}{ }^{\mathrm{DPH}}\right)$ showed a positive correlation with TTC, $(\mathrm{r})$ was +0.768 .

KEY WORDS: Antioxidant capacity; Fatty acids; Phenols; Tocopherols; Virgin olive oil

RESUMEN: Perfil fitoquímico y capacidad antioxidante de aceites de oliva virgen obtenidos de la variedad 'Roghiani' en diferentes regiones del norte de Libia. El objetivo de este trabajo fue determinar los ácidos grasos (FA), tocoferoles, fenoles, y la capacidad antioxidante (AC) de cinco aceites de oliva vírgenes (VOO) obtenidos de la variedad 'Roghiani', procedentes de diferentes regiones del norte de Libia y cosechados en 2015. Los parámetros fueron estudiados por primera vez en estos aceites. Se detectaron siete FA principales en muestras de VOO siendo los ácidos oleico, palmítico y linoleico los mayoritarios. El mayor porcentaje de ácido palmítico se presentó en los aceites de la zona de Tripoli VOO $(\mathrm{P} \leq 0.05)$. El ácido oleico fue el mayoritario en todas las muestras de VOO, siendo los de la zona de Gharyan los que tuvieron los valores más altos de ácido oleico, mayores proporciones $\mathrm{O} / \mathrm{L}$, de ácidos grasos monoinsaturados (MUFA), mayores contenidos de fenoles totales (TPC), de tocoferoles y tocotrienoles (TTC) y AC DPPH\% $(\mathrm{P} \leq 0.05)$. Se observó una estrecha relación positiva $(\mathrm{r}=+0.831)$ entre TPC y $\mathrm{AC}$, como $\left(1 / \mathrm{EC}_{50} \mathrm{DPPH}\right)$. Por otra parte, $1 / \mathrm{EC}_{50} \mathrm{DPPH}$, mostró una correlación positiva con TTC $(\mathrm{r}=+0.768)$.

PALABRAS CLAVE: Aceite de oliva virgen; Ácidos grasos; Capacidad antioxidante; Fenoles; Tocoferoles

ORCID ID: Esalami SM https://orcid.org/0000-0003-1120-6314, Dimic EB https://orcid.org/0000-0001-6986-477X, Rabrenovic BB https://orcid.org/0000-0002-4006-1612

Citation/Cómo citar este artículo: Esalami SM, Dimic EB, Rabrenovic BB. 2018. Phytochemical profile and antioxidant capacity of virgin olive oil obtained from the olive cultivar 'Roghiani' from different regions of northern Libya. Grasas Aceites 69 (2), e252. https://doi.org/10.3989/gya.1113172

Copyright: (C2018 CSIC. This is an open-access article distributed under the terms of the Creative Commons Attribution 4.0 International (CC BY 4.0) License. 


\section{INTRODUCTION}

Libya is one of the olive oil producers in North Africa, where olive oil is part of the basic culture. Between 2008/09 and 2013/14, the average oil production in the country amounted to 15,000 tons per year, which amounted to $0.5 \%$ of the total world production of olive oil. The use of olive oil in Libya is part of their culture and a large number of individual manufactures producing oil use the process of cold pressing (Elbeydi and Hamuda, 2016). VOO is a product from the extraction of the olive fruit and is considered to be one of the best sources of unsaturated fatty acids (mainly oleic acid), phenols, tocopherols and flavor components (Bendini et al., 2007). So, its nutritional properties are highly valued for their positive effects on human health (Ballus et al., 2014). The chemical composition of VOO consists of monounsaturated fatty acids (MUFA), polyunsaturated fatty acids (PUFA), and saturated fatty acids (SFA) (Del Coco et al., 2013). MUFA was essentially attributed to decreased endothelial activation, and LDL susceptibility to oxidation (Dabbou et al., 2011). The balances between oleic, linoleic, and linolenic acids, as well as other bioactive components have an important impact on the nutritional value and the oil's quality (Krichène et al., 2010). The most important phenolic compounds in VOO are phenolic acids and alcohols, secoiridoids, lignins and flavonoids. The phenolic composition and sensory properties of olive oil vary significantly depending on the olive variety (Yousfi et al., 2006). Phenolic compounds are important in terms of VOO quality because of their contribution to the oil's flavor and aroma. They also protect olive oil from oxidation through their antioxidant properties (Dabbou et al., 2011). The absolute concentration of phenols in olive oil is strongly affected by several factors, including the cultivar, the ripeness degree of the fruit, the climate, and the extraction procedures (Chtourou et al., 2013). Ben Othman et al., (2008) reported that olive oil is a rich source of natural antioxidants which may, by different mechanisms, act as an effective defence against reactive species. The olive oil supplemented diet is effective in the prevention of some diseases, including coronary atherosclerosis, the principal cause of death in western civilization (Fitó et al., 2000). The main objectives of this study were to investigate the phytochemical profile (fatty acids, phenolic acids and tocopherols), and in vitro, to determine the biological potential (antioxidant capacity) of the VOO obtained from the 'Roghiani' cultivar from five regions in northern Libya. Furthermore, the relationship and correlations between phytochemicals and antioxidant capacity have been highlighted. The investigation of these compounds supported by verifiable evidence may explain their role in the quality and authenticity of Libyan VOO as well as their contribution to human health.

\section{MATERIAL AND METHODS}

\subsection{Chemicals}

All standards, and reagents used in this study for the determination of phytochemicals in VOO, and their bioactivities were purchased from (SigmaAldrich Co., St. Louis, USA; J.T. Baker, Deventer, Teugseweg 207400 AA Deventer Netherlands). Other chemicals and solvents were of the highest commercial grade and purchased from (Merck, Darmstadt, Germany).

\subsection{VOO samples}

The study was carried out on the 'Roghiani' cultivar of olive fruits (Olea europea $\mathrm{L}$.) from Libya. The olive samples were hand-picked at the beginning of January, 2015, from five different geographic regions. This cultivar grows in the north of Libya (Gharyan: $32^{\circ} 10^{\prime} \mathrm{N}, 13^{\circ} 01^{\prime} \mathrm{E}$, Tarhuna: $32^{\circ} 26^{\prime} \mathrm{N}$, $96+13^{\circ} 10^{\prime} \mathrm{E}$, Msallata: $32^{\circ} 35^{\prime} \mathrm{N}, 14^{\circ} 2^{\prime} \mathrm{E}$, Tripoli: $32^{\circ} 53^{\prime} \mathrm{N}, 13^{\circ} 10^{\prime} \mathrm{E}$ and Q. B. Ghashir: $32^{\circ} 40^{\prime} \mathrm{N}, 13^{\circ}$ $\left.10^{\prime} \mathrm{E}\right)$. The mean rain precipitation registered in the north is about $383 \mathrm{~mm} /$ year, with a mean temperature of approximately $27^{\circ} \mathrm{C}$.

\subsection{Extraction of oil samples}

Olive fruit samples were collected and harvested from the regions described above. Within 3 days of harvesting, the fruits were washed, milled and the olive pastes were malaxed with a mixer for 40 min at $35-40{ }^{\circ} \mathrm{C}$. After separation at $3000 \mathrm{rpm}$ by a centrifugal separation process (Rapanelli, Foligno, Italy), the extracted olive oil samples were decanted and filtered. The VOO samples were stored in the refrigerator at $8{ }^{\circ} \mathrm{C}$ in dark glass bottles until further analysis. The samples then were tempered at room temperature for $24 \mathrm{~h}$ before analysis.

\subsection{Determination of fatty acids (FA)}

FA methyl esters were prepared using the standard method described by ISO E. 5509 (2000). FA composition was determined using the gas chromatography method described by ISO E. 5508 (1990), on the Hewlett-Packard (HP) 5971 instrument. Conditions for chromatographic determination were as follows: capillary column Supelco SP-2560 $100 \mathrm{~m}$ long, $0.25 \mathrm{~mm}$ internal diameter and film thickness of the stationary liquid phase $0.20 \mu \mathrm{m}$, injector temperature $230{ }^{\circ} \mathrm{C}$. The initial temperature of the column was maintained at $100{ }^{\circ} \mathrm{C}$ for $5 \mathrm{~min}$, followed by a rise in temperature at a rate of $6^{\circ} \mathrm{C} / \mathrm{min}$ to a final temperature of $240{ }^{\circ} \mathrm{C}$, which was maintained for the next $20 \mathrm{~min}$. The temperature of the mass spectrometry was $180^{\circ} \mathrm{C}$. The sample size was $1 \mathrm{ml}$. Helium was used as the carrier gas with a flow rate 
of $0.58 \mathrm{ml} / \mathrm{min}$. The qualitative determination was made on the basis of the mass spectrum and retention time. The quantitative determination was performed using a modified 0 method $100 \%$, where the correction factors used to define the standard solution of a mixture of methyl esters were determined by Supelco (37 component FAME Mix, $47885-\mathrm{U}$ ) according to the manufacturer.

\subsection{Iodine value (IV)}

IV was calculated from fatty acid percentages based on the formula given below (Krishnamurthy and Kellens, 1996):

$$
\begin{aligned}
\text { IV }(g / 100 g) & =(16: 1 \times 0.95)+(18: 1 \times 0.86) \\
& +(18: 2 \times 1.732)+(18: 3 \times 2.616)
\end{aligned}
$$

where: 16:1 palmitic acid; 18:1 oleic acid; 18:2 linoleic acid and 18:3 linolenic acid.

\subsection{Total phenol content (TPC)}

TPC was estimated according to the FolinCiocalteu spectrophotometric method described by Haiyan et al., (2007).

The TPC was calculated according to the following formula:

$$
\begin{aligned}
\mathrm{TPC}(\mathrm{mg} / \mathrm{kg}) & =\left[97.312 \times \mathrm{A}_{725 \mathrm{~nm}}-0.4865 / \mathrm{m}\right] \\
& \times 16.667
\end{aligned}
$$

where: $\mathrm{A}_{725 \mathrm{~nm}}=$ absorbance at $725 \mathrm{~nm} ; \mathrm{m}:=$ mass of sample $(\mathrm{g})$.

TPC was expressed as Gallic acid equivalents (GAE) in $\mathrm{mg} / \mathrm{kg}$ of oil.

\subsection{HPLC Analysis}

\subsubsection{Phenolics fractionation}

Phenols from the olive oil samples were extracted according to the modified procedure by Gouvinhas et al., (2014). $800 \mu \mathrm{l}$ of sample were accurately weighted into a $4 \mathrm{ml}$ vial and diluted with $400 \mu \mathrm{l}$ of hexane. The mixture was extracted with $600 \mu$ of $80 \%$ methanol by vigorous vortexing. After centrifuging for $10 \mathrm{~min}$ at $2500 \mathrm{rpm}$, the aqueous-methanolic layer was transferred into a $2 \mathrm{ml}$ volumetric flask, and oil layer was extracted two more times with $80 \%$ methanol. The pooled extract was filled with $80 \%$ methanol up to a final volume of $2 \mathrm{ml}$, filtered through a $0.45 \mu \mathrm{m}$ regenerated cellulose membrane filter, and analyzed by LC-DVD-MS / MS.

The contents of 38 common secondary bio molecules were determined by LC-DVD-MS / MS, according to the procedure by Orčić et al., (2014). $5 \mu \mathrm{l}$ of sample were injected. The separation was performed on a Zorbax Eclipse XDB-C18 column
$(50 \mathrm{~mm} \times 4.6 \mathrm{~mm}, 1.8 \mu \mathrm{m})$ held at $50{ }^{\circ} \mathrm{C}$. The components were eluted using a mobile phase consisting of $0.05 \%$ aqueous formic acid (A) and methanol (B), delivered at $1.0 \mathrm{ml} / \mathrm{min}$ at a gradient: $0 \mathrm{~min} 30 \%$ B, 6 min $70 \%, 9 \operatorname{min~100\% .~} 12$ min 100\%, post-time $3 \mathrm{~min}$. UV/ VIS signal in 190-700 $\mathrm{nm}$ range was monitored for identity confirmation purposes. The effluent was forwarded into the MS/MS detector without flow splitting. The ion source parameters were as follows: nebulizer pressure $50 \mathrm{psi}$, drying gas $\left(\mathrm{N}_{2}\right)$ temperature and flow rate of $350{ }^{\circ} \mathrm{C}$ and $10 \mathrm{l} /$ min, respectively, capillary voltage $4000 \mathrm{~V}$, negative polarity. The compounds were monitored using the dynamic SRM mode. A series of standards, ranging from $1.53 \mu \mathrm{g} / \mathrm{ml}$ to $25.0 \mu \mathrm{g} / \mathrm{ml}$, was prepared by sequential 1:1 dilution. All compounds were quantified according to SRM signals except for tyrosol, due to poor MS/MS response, which required the use of a UV signal $(280 \mathrm{~nm}$ with $20 \mathrm{~nm}$ bandwidth vs. reference wavelength of $550 \mathrm{~nm}$ with $100 \mathrm{~nm}$ bandwidth).

\subsubsection{Tocopherol fractionation}

The determination of tocopherols was carried out using HPLC (Waters, M600E, USA) on a reversedphase Nucleosil 50-5 C18 column with fluorescence detection using a method based on the procedure of Carpenter, (1979), with slight modifications. The following procedures were applied: $20 \mathrm{ml} \mathrm{95 \%}$ ethanol, $0.12 \mathrm{~g}$ of pyrogallol, and $30 \mathrm{ml} \mathrm{KOH}$ solution $(8.9 \mathrm{~mol} / \mathrm{l})$ were added to $0.5 \mathrm{ml}$ of oil, and then the solution was heated for $30 \mathrm{~min}$ at $60^{\circ} \mathrm{C}$ with a reflux and stirring. Once the saponification process was completed, the content was cooled, and transferred to the volumetric flask $(50 \mathrm{ml})$, and topped with ethanol. An aliquot of $5 \mathrm{ml}$ was then transferred to the separation funnel and $5 \mathrm{ml}$ of cold deionized water and $5 \mathrm{ml}$ of hexane were added. The mixture was shaken using vortex for $3 \mathrm{~min}$ and $4 \mathrm{ml}$ of the solution were then dried under a nitrogen blanket. The dry matter was then dissolved in $4 \mathrm{ml}$ of methanol. The sample was then filtered using a membrane syringe filter and injected into the HPLC system. The mobile phase was $100 \mathrm{ml}$ of $95 \%$ methanol at a flow rate of $1.2 \mathrm{ml} / \mathrm{min}$. Detection was done by the fluorescence detector (Shimadzu RF-535, Japan) operated with the excitation wavelength at $\lambda=290$ $\mathrm{nm}$ and the emission wavelength at $\lambda=330 \mathrm{~nm}$. The relative retention time and maximum values of absorption at the given relative retention time were used for the identification of tocopherols in the oil samples.

\subsection{Total tocopherol and tocotrienol contents (TTC)}

The contents of total tocopherols and tocotrienols were determined using a method adopted by (Paquot et al., 1967). Briefly, the first step in this 
procedure was the saponification and extraction of the unsaponified matter that was soluble in benzene. The benzene solution was then used to perform a color reaction. The absorption of the solution was measured at $520 \mathrm{~nm}$ using a blank probe.

\subsection{DPPH scavenging assay}

The antioxidant capacity of the VOO extracts in the current study was assessed by the evaluation of the free radical scavenging effect on 2,2-diphenyl1-picrylhydrazyl (DPPH) radical, according to the method proposed by Martínez and Maestri, (2008). The absorbance was read at $515 \mathrm{~nm}$ using toluene as the blank.

The ability to scavenge DPPH radicals, i.e. $\mathrm{AC}_{\mathrm{DPPH}}$ was calculated by the following formula:

$\mathrm{AC}^{\mathrm{DPPH}}(\%)=\left[\mathrm{A}_{\mathrm{c}}-\mathrm{A}_{\mathrm{s}} / \mathrm{A}_{\mathrm{c}}\right] \times 100$

where: $A_{C}=$ absorbance of the control; $A_{S}=$ absorbance of the sample.

$\mathrm{EC}_{50}{ }^{\mathrm{DPPH}}$ values were calculated as the inhibitory concentration of the oil necessary to decrease the initial $\mathrm{DPPH}^{\bullet}$ absorbance by $50 \%$. A lower $\mathrm{EC}_{50}$ value indicates a higher antiradical capacity. $\mathrm{EC}_{50}{ }^{\mathrm{DPPH}}(\mathrm{mg} / \mathrm{ml})$ values were expressed as antioxidant capacity $(\mathrm{AC})$ and $1 / \mathrm{EC}_{50}{ }^{\mathrm{DPPH}}(\mathrm{ml} / \mathrm{mg})$.

\subsection{Statistical analysis}

All results are presented as a mean value \pm standard deviation $(n=3)$. One way analysis of variance (ANOVA) with a Tukey's test was used to determine significant differences among the data. The statistically significant level was fixed at $(P \leq 0.05)$. The degree of linear relationship between two variables was measured using Pearson's correlation coefficient (r). The $\mathrm{EC}_{50}$ values were calculated using the best-fit regression model. All the data were analyzed using Microsoft Office Excel 2007 Software.

\section{RESULTS}

\subsection{Fatty acid composition (FA)}

The results for FA are summarized in Table 1. It can be seen that the highest percentage of palmitic acid (18.77 \pm 0.05$)$ was found in Tripoli VOO $(p \leq 0.05)$ followed by Tarhuna, Q. B. Ghashir, Msallata, and Gharyan VOO, which had the lowest value of palmitic acid (13.20 \pm 0.23$)$. Essential FAs (oleic, linoleic and linolenic) are also registered in Table 1. Oleic acid was the dominant factor with respect to linoleic and linolenic acids in terms of discriminating olive oils from each other.

The highest percentage of oleic acid was found in Gharyan VOO (70.09 \pm 0.18$)$; while the lowest percentage was detected in Tripoli VOO (52.14 \pm 0.05$)$; although this oil had the highest percentage of linoleic acid $(23.11 \pm 0.03)$. The lowest percentage was presented in Gharyan VOO (11.55 \pm 0.34$)$. Our results showed that linolenic acid was in a low percentage compared with oleic and linoleic acids. Q. B. Ghashir VOO had the highest percentage of linolenic acid $(0.81 \pm 0.02)$. No significant difference was found among Gharyan, Msallata, or Tripoli VOO, or between Tarhuna and Msallata VOO.

The results of IV are presented in Table 1. IV was calculated as g/100 $\mathrm{g}$ of oil. IV showed the following order: Tripoli (89.18) > Q.B. Ghashir (88.97)

TABLE 1 . Fatty acids, iodine value and $\mathrm{O} / \mathrm{L}$ ratio

\begin{tabular}{lcccrc}
\hline FA (g/100g) & Gharyan & Tarhuna & Msallata & Tripoli & Q. B. Ghashir \\
\hline $16: 0$ & $13.20 \pm 0.23^{\mathrm{a}}$ & $17.76 \pm 0.02^{\mathrm{b}}$ & $16.22 \pm 0.02^{\mathrm{c}}$ & $18.77 \pm 0.05^{\mathrm{d}}$ & $17.44 \pm 0.04^{\mathrm{e}}$ \\
$16: 1$ & $1.08 \pm 0.01^{\mathrm{a}}$ & $2.02 \pm 0.03^{\mathrm{b}}$ & $1.69 \pm 0.01^{\mathrm{c}}$ & $2.48 \pm 0.01^{\mathrm{d}}$ & $2.18 \pm 0.02^{\mathrm{e}}$ \\
$18: 0$ & $2.98 \pm 0.08^{\mathrm{a}}$ & $2.43 \pm 0.04^{\mathrm{b}}$ & $2.66 \pm 0.01^{\mathrm{c}}$ & $2.39 \pm 0.01^{\mathrm{b}}$ & $2.18 \pm 0.02^{\mathrm{e}}$ \\
$18: 1$ & $70.09 \pm 0.18^{\mathrm{a}}$ & $55.66 \pm 0.12^{\mathrm{b}}$ & $61.35 \pm 0.13^{\mathrm{c}}$ & $52.14 \pm 0.05^{\mathrm{d}}$ & $55.77 \pm 0.05^{\mathrm{b}}$ \\
$18: 2 \mathrm{n}-6$ & $11.55 \pm 0.34^{\mathrm{a}}$ & $21.02 \pm 0.06^{\mathrm{b}}$ & $17.01 \pm 0.10^{\mathrm{c}}$ & $23.11 \pm 0.03^{\mathrm{d}}$ & $21.26 \pm 0.05^{\mathrm{b}}$ \\
$18: 3 \mathrm{n}-3$ & $0.64 \pm 0.02^{\mathrm{a}}$ & $0.76 \pm 0.05^{\mathrm{b}}$ & $0.70 \pm 0.02^{\mathrm{c}}$ & $0.75 \pm 0.02^{\mathrm{b}}$ & $0.81 \pm 0.02^{\mathrm{d}}$ \\
$20: 0$ & $0.46 \pm 0.01^{\mathrm{a}}$ & $0.36 \pm 0.03^{\mathrm{b}}$ & $0.36 \pm 0.01^{\mathrm{b}}$ & $0.36 \pm 0.02^{\mathrm{b}}$ & $0.36 \pm 0.01^{\mathrm{b}}$ \\
$\Sigma$ SFA $^{\mathrm{A}}$ & 16.64 & 20.55 & 19.24 & 21.52 & 19.98 \\
$\Sigma \mathrm{MUFA}^{\mathrm{B}}$ & 71.17 & 57.68 & 63.04 & 54.62 & 57.95 \\
$\Sigma \mathrm{PUFA}^{\mathrm{C}}$ & 12.19 & 21.7 & 17.71 & 23.86 & 22.07 \\
IV $^{\mathrm{D}}(\mathrm{g} / 100 \mathrm{~g})$ & $82.98 \pm 0.39^{\mathrm{a}}$ & $88.18 \pm 0.11^{\mathrm{b}}$ & $85.66 \pm 0.12^{\mathrm{c}}$ & $89.18 \pm 0.02^{\mathrm{b}}$ & $88.97 \pm 0.11^{\mathrm{b}}$ \\
O/L $^{\mathrm{E}}$ & 6.07 & 2.65 & 3.61 & 2.26 & 2.62 \\
\hline
\end{tabular}

Values are means \pm standard deviations $(n=3)$. Different letters in the same row indicate significantly different values $(\mathrm{p} \leq 0.05)$. A, Total saturated fatty acids. B, Total monounsaturated fatty acids. C, Total polyunsaturated fatty acids. D, Iodine value. E, Oleic acid / linoleic acid ratio. 
$>$ Tarhuna (88.18) > Msallata (85.66) > Gharyan (82.98). There was a significant difference $(p \leq 0.05)$ between the VOO obtained from the Gharyan and Msallata regions, although no significant difference between other VOO regions was found.

The $\mathrm{O} / \mathrm{L}$ ratio is also presented in Table 1 , and had the following order: Gharyan (6.07) > Masllata (3.61) $>$ Tarhuna (2.65) > Q.B. Ghasheir (2.62) > Tripoli (2.26). The statistical analysis showed significant differences $(p \leq 0.05)$ between Gharyan VOO and other VOO regions. On the other hand, no significant differences $(p \leq 0.05)$ were found between the VOO obtained from Tripoli, Q. B. Ghashir or Tarhuna.

\subsection{Phenols}

The total phenol content (TPC) was presented in Table 2. The TPC ranged from (56 \pm 21.49 to 238.3 $\pm 16.26 \mathrm{mg} \mathrm{GAE} / \mathrm{kg}$ ). There was a significant difference between Gharyan VOO and the VOO from other regions; while no significant difference was found $(p \leq 0.05)$ among the VOO from Tarhuna, Msallata or the Q. B. Ghashir regions. The fractionation of phenols analyzed by HPLC is also presented in Table 2. The Phenol alcohols (tyrosol and hydroxytyrosol) ranged from $4.36 \pm 0.33$ to $11.4 \pm$ 1.50 and $0.33 \pm 0.01$ to $10.90 \pm 1.20 \mathrm{mg} / \mathrm{kg}$, respectively. The statistical analysis showed significant differences $(p \leq 0.05)$ among the VOO from all regions.

Other phenolic acids in the VOO samples were present in very low concentrations, in all cases $<0.1 \mathrm{mg} / \mathrm{kg}$. The concentration of caffeic acid was $<0.07$ in Gharyan, Tripoli and Q. B. Ghashir VOO. The chrysoeriol level ranged from 0.07 \pm 0.01 to $0.15 \pm 0.01 \mathrm{mg} / \mathrm{kg}$. Q. B. Ghashir possessed the highest level, and the lowest level was in
Gharyan VOO. The Naringenin level ranged from $0.18 \pm 0.02$ to $0.36 \pm 0.01 \mathrm{mg} / \mathrm{kg}$. The Apigenin level ranged from $0.34 \pm 0.02$ to $0.70 \pm 0.02 \mathrm{mg} /$ kg. Q. B. Ghashir VOO was dominant. The lowest level was found in Tarhuna VOO.

\subsection{Tocopherols and tocotrienols}

As a further important criterion for the assessment of olive oil, the total tocopherol and tocotrienol contents (TTC) are presented in Table 3. The TTC ranged from $(221.6 \pm 4.31$ to $528.6 \pm 14.49 \mathrm{mg} /$ $\mathrm{kg}$ ). The highest TTC was found in Gharyan VOO, and the lowest TTC was in Tripoli VOO. The statistical analysis indicated that there were significant differences $(p \leq 0.05)$ among the VOO in all regions.

The tocopherol compositions analyzed by HPLC are presented in Table 3 . There is a certain difference $(p \leq 0.05)$ in the tocopherol composition in the VOO from the different regions. $\alpha$-tocopherols possessed a higher percentage compared with $\beta+\gamma, \beta$-tocopherol in all VOO samples.

The $\alpha$-tocopherol content of the VOO samples ranged from $29.35 \pm 1.17$ to $97.52 \pm 4.88 \mathrm{mg} / \mathrm{kg}$ in Gharyan, Msallata VOO respectively, whereas; $\beta+\gamma$ - tocopherol was found at $1.37 \pm 0.07$ in Tripoli VOO and up to $4.69 \pm 0.23 \mathrm{mg} / \mathrm{kg}$ in Tarhuna VOO. $\delta$-tocopherol ranged from $0.30 \pm 0.02$ in Tripoli VOO to $1.16 \pm 0.06 \mathrm{mg} / \mathrm{kg}$ in Gharyan VOO.

\subsection{DPPH assay}

The antioxidant capacity was determined by $\mathrm{DPPH}^{\circ}\left(\mathrm{AC}^{\mathrm{DPPH}}\right)$ and is presented in Figure 1. As shown this figure Gharyan VOO showed significantly higher $(P \leq 0.05), \mathrm{AC}^{\mathrm{DPPH}}$ at $96.2 \%$ when the

TABLE 2. Total phenol contents and their fractionation

\begin{tabular}{lccccc}
\hline Compounds & Gharyan & Tarhuna & Msallata & Tripoli & Q. B. Ghashir \\
\hline Tyrosol & $11.4 \pm 1.50^{\mathrm{a}}$ & $4.83 \pm 0.30^{\mathrm{b}}$ & $4.36 \pm 0.33^{\mathrm{b}}$ & $5.76 \pm 0.64^{\mathrm{b}}$ & $8.60 \pm 0.71^{\mathrm{c}}$ \\
Hydroxytyrosol & $10.9 \pm 1.20^{\mathrm{a}}$ & $0.36 \pm 0.02^{\mathrm{b}}$ & $0.33 \pm 0.01^{\mathrm{b}}$ & $1.08 \pm 0.14^{\mathrm{c}}$ & $10.7 \pm 0.50^{\mathrm{a}}$ \\
$p$-coumaric acid & $0.03 \pm 0.01^{\mathrm{a}}$ & $0.21 \pm 0.01^{\mathrm{b}}$ & $0.48 \pm 0.02^{\mathrm{c}}$ & $0.28 \pm 0.03^{\mathrm{b}}$ & $0.09 \pm 0.00^{\mathrm{a}}$ \\
Vanillic acid & $<0.1$ & $<0.1$ & $0.18 \pm 0.03$ & $<0.1$ & $<0.1$ \\
Caffeic acid & $<0.07$ & $0.07 \pm 0.00$ & $0.09 \pm 0.02$ & $<0.07$ & $<0.07$ \\
Ferulic acid & $<0.02$ & $0.04 \pm 0.01$ & $0.09 \pm 0.01$ & $0.06 \pm 0.00$ & $<0.02$ \\
Luteolin & $0.90 \pm 0.11^{\mathrm{a}}$ & $0.91 \pm 0.05^{\mathrm{a}}$ & $0.73 \pm 0.03^{\mathrm{a}}$ & $0.86 \pm 0.08^{\mathrm{a}}$ & $1.38 \pm 0.07^{\mathrm{b}}$ \\
p-hydyroxybenzoic acid & $<0.03$ & $<0.03$ & $0.08 \pm 0.01$ & $<0.03$ & $<0.03$ \\
Protocatechuic acid & $<0.01$ & $<0.01$ & $0.04 \pm 0.00$ & $<0.01$ & $<0.01$ \\
Quinic acid & $<0.1$ & $0.13 \pm 0.02$ & $<0.1$ & $<0.1$ & $<0.1$ \\
Naringenin & $0.18 \pm 0.02^{\mathrm{a}}$ & $0.21 \pm 0.01^{\mathrm{a}}$ & $0.35 \pm 0.01^{\mathrm{b}}$ & $0.25 \pm 0.03^{\mathrm{c}}$ & $0.36 \pm 0.01^{\mathrm{b}}$ \\
Apigenin & $0.40 \pm 0.05^{\mathrm{ab}}$ & $0.34 \pm 0.02^{\mathrm{a}}$ & $0.44 \pm 0.03^{\mathrm{b}}$ & $0.48 \pm 0.05^{\mathrm{b}}$ & $0.70 \pm 0.02^{\mathrm{c}}$ \\
chrysoeriol & $0.07 \pm 0.01^{\mathrm{a}}$ & $0.08 \pm 0.01^{\mathrm{ab}}$ & $0.08 \pm 0.00^{\mathrm{a}}$ & $0.10 \pm 0.01^{\mathrm{b}}$ & $0.15 \pm 0.01^{\mathrm{c}}$ \\
TPC $^{\mathrm{A}}$ & $238.3 \pm 16.26^{\mathrm{a}}$ & $144.2 \pm 29.69^{\mathrm{b}}$ & $139.4 \pm 7.70^{\mathrm{b}}$ & $56.0 \pm 21.49^{\mathrm{c}}$ & $136.8 \pm 0.07^{\mathrm{b}}$ \\
\hline
\end{tabular}

Values are means \pm standard deviations $(n=3)$. Different letters in the same row indicate significantly different values $(p \leq 0.05)$. A, Total phenolic content (mg GAE/kg). 
TABLE 3. Tocopherols and tocotrienols

\begin{tabular}{lcccc}
\hline VOO samples & $\boldsymbol{a}$ - tocopherol & $\boldsymbol{\beta}+\boldsymbol{\gamma}$ - tocopherol & $\boldsymbol{\delta}$ - tocopherol & TTC $^{\mathbf{A}}$ \\
\hline Gharyan & $29.35 \pm 1.17^{\mathrm{a}}$ & $1.89 \pm 0.09^{\mathrm{a}}$ & $1.16 \pm 0.06^{\mathrm{a}}$ & $528.6 \pm 14.49^{\mathrm{a}}$ \\
Tarhuna & $78.89 \pm 3.94^{\mathrm{b}}$ & $4.69 \pm 0.23^{\mathrm{b}}$ & $0.52 \pm 0.03^{\mathrm{b}}$ & $253.4 \pm 34.86^{\mathrm{b}}$ \\
Msallata & $97.52 \pm 4.88^{\mathrm{c}}$ & $3.54 \pm 0.28^{\mathrm{c}}$ & $0.66 \pm 0.03^{\mathrm{c}}$ & $334.5 \pm 44.90^{\mathrm{c}}$ \\
Tripoli & $48.71 \pm 2.44^{\mathrm{d}}$ & $1.37 \pm 0.07^{\mathrm{d}}$ & $0.30 \pm 0.02^{\mathrm{d}}$ & $221.6 \pm 4.31^{\mathrm{d}}$ \\
Q. B. Ghashir & $43.93 \pm 2.20^{\mathrm{e}}$ & $1.76 \pm 0.09^{\mathrm{e}}$ & $0.52 \pm 0.03^{\mathrm{eb}}$ & $452.1 \pm 18.31^{\mathrm{e}}$ \\
\hline
\end{tabular}

Values are means \pm standard deviations $(\mathrm{n}=3)$. Different letters in the same column indicate significantly different values $(p \leq 0.05)$. $\mathrm{A}$, Total tocopherols and tocotrienols content $(\mathrm{mg} / \mathrm{kg})$.

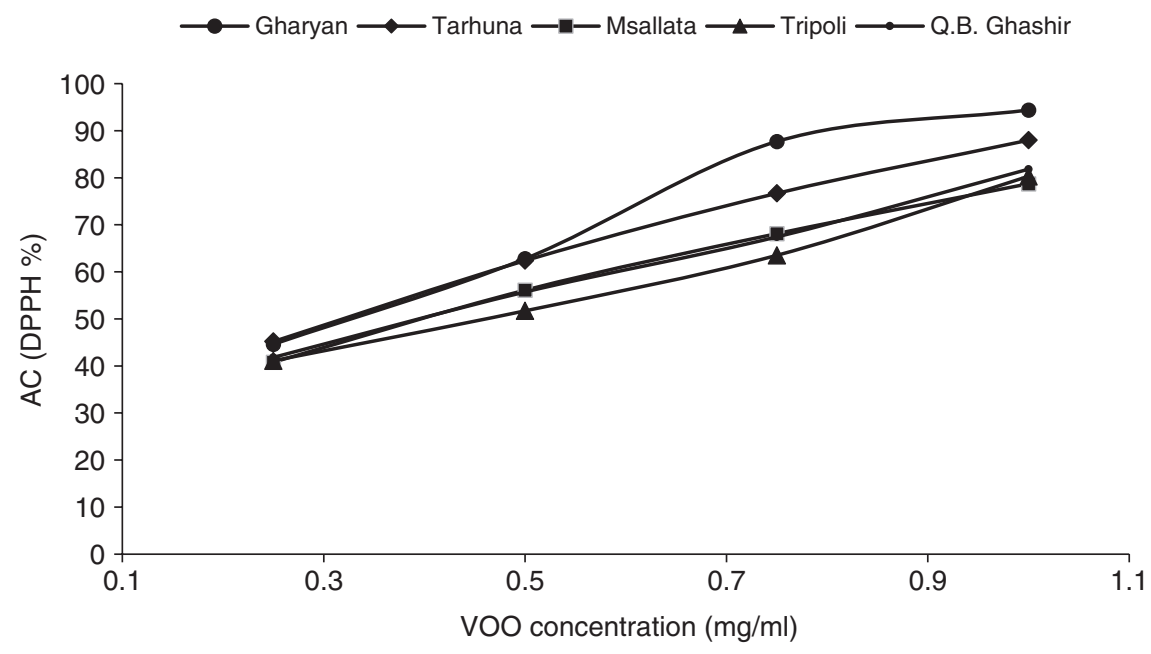

FIGURE 1. DPPH radical scavenging activity $(\%)$ versus concentration $(\mathrm{mg} / \mathrm{ml})$

concentration of the sample was $(1.00 \mathrm{mg} / \mathrm{ml})$ compared to other VOO samples. The scavenging effect on the DPPH radical followed the order: Gharyan $>$ Q. B. Ghashir > Msallata > Tarhuna VOO; whereas Tripoli VOO showed the lowest $\mathrm{AC}^{\mathrm{DPPH}} \%$, which was $76.9 \%$ at $1.00 \mathrm{mg} / \mathrm{ml}$.

The $\mathrm{EC}_{50}{ }^{\mathrm{DPPH}}$ values of VOO in all DPPH assays were calculated and listed in Table 4 . The $\mathrm{EC}_{50} \mathrm{DPPH}$ value of VOO in this study ranged from 0.20 to $0.41(\mathrm{mg} / \mathrm{ml})$. Consequently, the highest $\mathrm{EC}_{50}{ }^{\mathrm{DP}}$ was registered for Msallata VOO, while the lowest $\mathrm{EC}_{50} \mathrm{DPPH}$ was found in Gharyan VOO $(P \leq 0.05)$. As shown in Table 4. Gharyan VOO had the highest antiradical power ARP $\left(1 / \mathrm{EC}_{50}{ }^{\mathrm{DPH}}\right)$ followed by Q. B. Ghashir, Tarhuna, Tripoli and the lowest ARP was found in Msallata VOO.

\section{DISCUSSION}

\subsection{Fatty acid composition (FA)}

Based on the FA results in the current study, seven principal FAs were detected in the VOO samples. Oleic, palmitic, and linoleic acids were dominant in the VOO, the other FA occurred in small amounts.
TABLE 4. Antioxidant capacity (DPPH)

\begin{tabular}{lccc}
\hline VOO sample & $\begin{array}{c}\text { DPPH scavenging } \\
(\%)^{*}\end{array}$ & $\mathbf{E C}_{\mathbf{5 0}}{ }^{\mathbf{D P H}}$ & $\begin{array}{c}\text { ARP 1/ } \\
\mathbf{E C}_{\mathbf{5 0}} \text { DPPH }\end{array}$ \\
\hline Gharyan & $96.2 \pm 0.20^{\mathrm{a}}$ & 0.20 & 5.00 \\
Tarhuna & $82.2 \pm 1.00^{\mathrm{b}}$ & 0.37 & 2.73 \\
Msallata & $88.2 \pm 1.00^{\mathrm{c}}$ & 0.41 & 2.43 \\
Tripoli & $76.9 \pm 1.00^{\mathrm{d}}$ & 0.38 & 2.60 \\
Q. B. Ghashir & $94.2 \pm 0.20^{\mathrm{a}}$ & 0.35 & 2.87 \\
\hline
\end{tabular}

* Values are means \pm standard deviations $(n=3)$. Different letters in the same column indicate significantly different values $(p \leq 0.05)$. ARP, antiradical power $(\mathrm{ml} / \mathrm{mg}), \mathrm{EC}_{50}{ }^{\mathrm{DPH}}(\mathrm{mg} /$ $\mathrm{ml})$, the concentration of sample needed to decrease the initial $\mathrm{DPPH}^{*}$ concentration by $50 \%$.

FA may differ from sample to sample. Oleic acid ranged from $(11.55-70.09 \%)$ in all VOO samples. Chtourou et al., (2013) also studied the VOO from Tunisia (Chemlali Sfax and Arbequina), and found that the Arbequina oil had the highest percentage of oleic acid $(63.85 \%)$ compared to (Chemlali Sfax); whereas the lowest percentage of this FA was $(58.04 \%)$. These results are in agreement with the results in this study which observed that oleic acid 
was the dominant fatty acid. The FA distribution in olive oil according to the International Olive Oil Council (1984) is $55.0-83.0 \%$ oleic, $7.5-20.0 \%$ palmitic, 3.5-21.0\% linoleic and 0.5-5.0\% stearic acid. Boggia et al., (2005) determined the FA in olive oil of the cultivar Colombia to be $61.96-72.03 \%$ oleic, 9.78$18.30 \%$ linoleic, $13.15-14.77 \%$ palmitic and 2.35 $3.90 \%$ stearic acids. Wiesman, (2009) examined the quality of desert-grown olive oils and he observed high oleic acid contents in those cultivars grown under relatively saline water conditions. However, there are contradictory reports on the effects of the temperature and latitude and longitude of the growing locations of olive oil and their phytochemical compounds such as fatty acids and polyphenols.

In general, Tripoli VOO had the highest value for SFA and PUFA; whereas Gharyan VOO had the highest value for MUFA. Chourou et al., (2013) also studied SFA, MUFA, and PUFA in VOO from Tunisia and determined that the SFA of Chemlali Sfax oil was $21.05 \%$, and MUFA was $66.07 \%$ in Arbequina oil and PUFA was $18.11 \%$ in Chemlali oil. Libyan VOO from different regions had a similar percentage of all unsaturated fatty acids.

IV is a good indicator often used to determine the amount of unsaturation in FA. This unsaturation is in the form of double bonds which react with iodine compounds. The higher the iodine value, the more $\mathrm{C}=\mathrm{C}$ bonds are present in the fat. This study showed that Tripoli VOO had the highest iodine value $(89.18 \%$ ), while Gharyan VOO had the lowest iodine value (82.98\%). Dabbou et al., (2010) determined the IV in Chemlali cultivars from Tunisia, and these authors observed that the iodine value in Chemlali Sfax oil was $87.83 \%$ and Chemlali Zarzis oil was $80.20 \%$.

The results in this study showed that the IV is at a similar value to Tunisian VOO. Our results also showed the positive relationship between IV and PUFA. The Pearson's correlation coefficient was $r=0.983$.

The $\mathrm{O} / \mathrm{L}$ ratio is in accordance with the oleic to a linoleic ratio $(\mathrm{O} / \mathrm{L}$ ratio) which affects the taste of VOO, a condiment largely responsible for flavor and healthy effects of the Mediterranean diet (Boskou et al., 2006). Gharyan VOO had the highest $\mathrm{O} / \mathrm{L}$ ratio which was 6.07: whereas Tripoli VOO had the lowest $\mathrm{O} / \mathrm{L}$ ratio (2.26).

Dabbou et al., (2010) also determined the O/L ratio in Chemlali cultivars from Tunisia. The authors found that the O/L ratio of Chemlali Sfax oil was 3.31 and in Chemlali Zarzis oil it was 12.17. The results in this study showed that the $\mathrm{O} / \mathrm{L}$ ratio is similar to Tunisian oil.

\subsection{Phenols}

According to the results presented in Table 2, the highest TPC was found in Gharyan VOO, and the lowest TPC was found in Tripoli VOO. Phenols are very important for assessing the quality of edible oils. Nakbi et al., (2010) also studied the TPC in the Chetoui and Chemlali cultivars from Tunisia and reported that the total phenolic contents were $113.40 \pm 1.32$ and $53.19 \pm 1.50 \mathrm{mg} \mathrm{GAE} / \mathrm{kg}$ for Chetoui and Chemlali cultivars, respectively. These results were similar to the results in this study.

The fractionation of phenols by using HPLC showed that Gharyan VOO was the highest; while the Msallata VOO was the lowest. The tyrosol:hydroxytyrosol ratio was lower in Tarhuna, Msallata, Tripoli, and Q. B. Ghashir VOO than Gharyan VOO. Other phenols were present in very small amount; in all cases $<0.1 \mathrm{mg} / \mathrm{kg}$, which is consistent with reports by other authors for other olive oils (Caponio et al., 1999). However, several phenolic compounds described by these authors, such as vanillic, $p$-hydroxybenzoic, protocatechuic, quinic acids were $<0.1$. Monasterio et al., (2013) reported that hydroxytyrosol had much higher antioxidant capacity than that observed for tyrosol.

\subsection{Tocopherols and tocotrienols}

Matthäus and Özcan (2011) reported the tocopherols in four olive oils from different regions of Turkey. The authors reported that the tocopherols ranged between 2.38 in Sarlulak and $21.51 \mathrm{mg} / \mathrm{kg}$ in Gemlik. The $\alpha$-tocopherol contents of the samples were found between 0.56 in Sarmlak and $20.29 \mathrm{mg} /$ $\mathrm{kg}$ in Gemlik. Our results showed that Libyan VOO from different regions had higher amounts. The percentages of different tocopherols in the olive oil were as follows: $88.5 \% \alpha$-tocopherol, $9.9 \% \beta+\gamma$ tocopherol and 1.6\% $\beta$-tocopherol (IOOC, 1984). Nakbi et al., (2010) studied the TTC in the Chetoui and Chemlali varieties from Tunisia and these authors reported that the Chemlali oil had the highest TTC (234.30 $\pm 35.25 \mathrm{mg} / \mathrm{kg})$; whereas Chetoui oil had the lowest TTC $(270.00 \pm 12.44 \mathrm{mg} / \mathrm{kg})$. These results were similar to the Tripoli VOO in our study.

\subsection{Antioxidant capacity by DPPH assay}

The In vitro DPPH• assay has been widely accepted as a tool for estimating the free radical scavenging activity of antioxidants (Brahmi et al., 2012). Moreover, this assay has been accepted as a model for measuring the free radicals originating from lipids (Arabshahi-Delouee and Urooj, 2007).

It was observed that the (\%) of inhibition in the DPPH assays of the VOO from different regions or varieties, were increased through the increasing concentration of VOO samples, which depended primarily on the content of phenols and tocopherols, which play a key role of antioxidant. The value can be determined graphically by plotting the $\% \mathrm{DPPH}^{\circ}$ inhibition against the concentration $(\mathrm{mg} / \mathrm{ml})$ of $\mathrm{VOO}$, then using the regression equation to calculate 

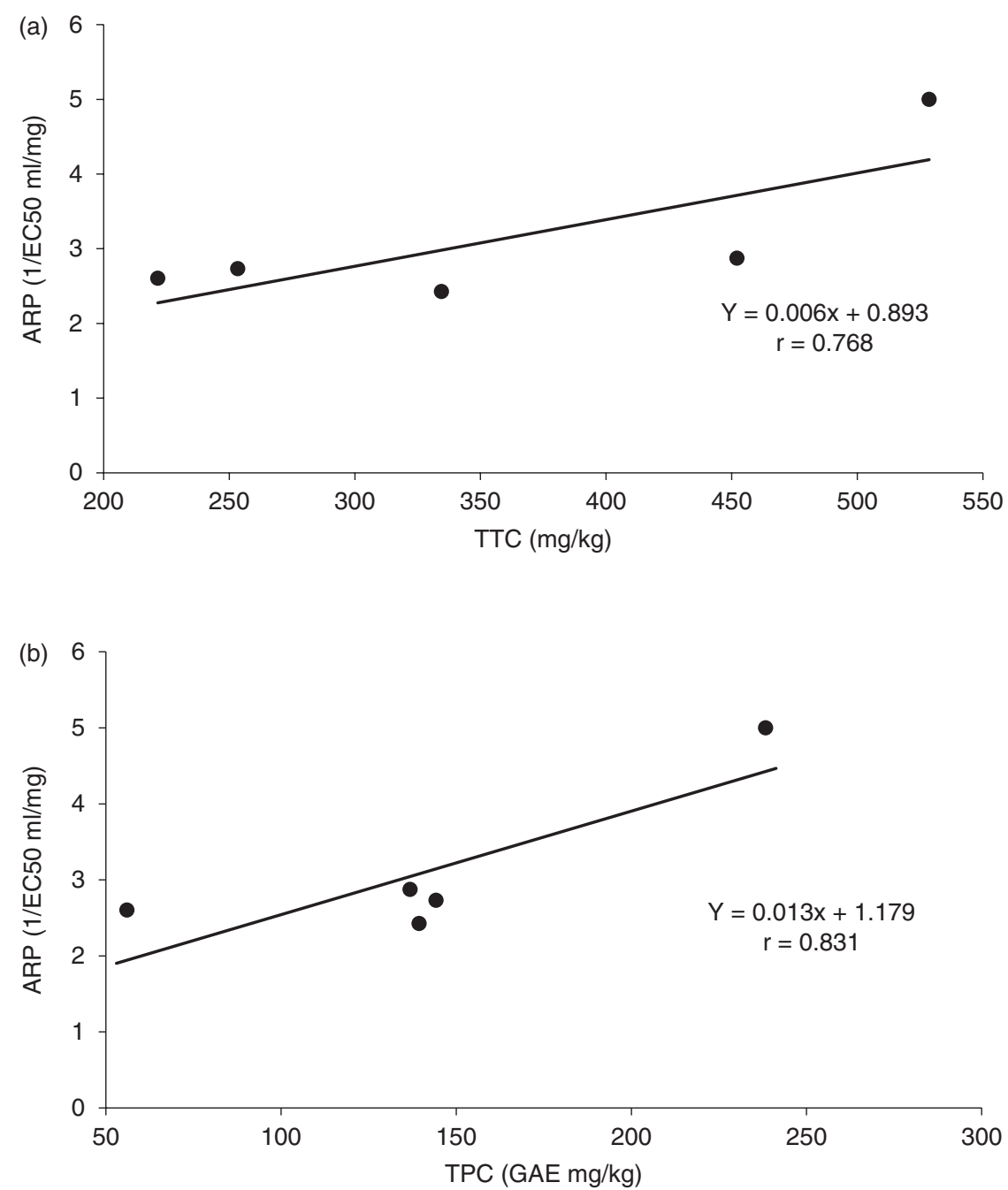

Figure 2. a) Pearson's correlation coefficient (r) between TTC and ( $\left.A R P^{\mathrm{DPPH}}\right)$; b) Between TPC and (ARP $P^{\mathrm{DPPH}}$ ) in VOO samples

$\mathrm{EC}_{50}$. The higher $\mathrm{EC}_{50}$ value corresponds to a lower scavenging activity on DPPH radicals.

The $\mathrm{EC}_{50}{ }_{\mathrm{DPPH}}$ in this study was higher than the $\mathrm{EC}_{50}{ }_{\mathrm{DPH}}$ results reported by (Chtourou et al., 2013). These authors found that the $\mathrm{EC}_{50}{ }^{\mathrm{DPPH}}$ value of Chemlali Sfax oil was $(0.01 \mathrm{mg} / \mathrm{ml})$, while Arbequina oil was $(0.02 \mathrm{mg} / \mathrm{ml})$.

\subsection{Correlation (r) among phytochemicals and antioxidant capacity in VOO samples}

Phenolic compounds and tocopherols play a key role in the stability of VOO. Indeed, phenolic content is important in the evaluation of the extra VOO nutritive quality because phenolic compounds protect the triacylglycerols from oxidation and contribute to the oil's flavor and aroma. All EC $\mathrm{EC}_{50} \mathrm{DPH}$ values were transformed into their reciprocal values, $1 / \mathrm{EC}_{50}{ }_{\mathrm{DPH}}$. Reciprocal values are more representative of the presented activities because they follow the increasing trend of the sample efficiencies in the tested assay. These values were investigated with respect to the correlation with the TPC and TTC, and quantified in the VOO samples. In order to evaluate the relationship between those phytochemicals and AC. Pearson's correlation coefficient (r) was analyzed, and some strong significant correlations were achieved $(0.8 \leq \mathrm{r} \leq 1)$. The results of correlation analysis are presented in Figure $2 \mathrm{a}$. A strong positive relationship between $\mathrm{TPC}$ and $\mathrm{AC}$ as $\left(1 / \mathrm{EC}_{50}{ }^{\mathrm{DPPH}}\right)$ was observed, and Pearson's correlation coefficient was $(r=+0.831)$. On the other hand, $\left(1 / \mathrm{EC}_{50}{ }^{\mathrm{DPPH}}\right)$ showed a moderate positive correlation with TTC $(\mathrm{r}=+0.768)$ which is shown in Figure $2 \mathrm{~b}$. These results suggest that TPC and TTC are good predictors of in vitro antioxidant activity.

\section{CONCLUSIONS}

The virgin olive oil obtained from the 'Roghiani' cultivar from different regions of northern Libya shows variation in its phytochemical contents and 
antioxidant properties. Seven principal FAs were detected in the VOO samples. Palmitic, oleic, and linoleic acids were dominant in the VOO. The other FA occurred in small amounts. The highest percentage of palmitic acid was presented in Tripoli VOO $(P \leq 0.05)$. Oleic acid was the dominant fatty acid compared to linoleic and linolenic acids in all the VOO samples. Gharyan VOO possessed the highest percentage of oleic acid, O/L ratio, MUFA, TPC, TTC, and AC ${ }^{\mathrm{DPPH}}$ $\%(P \leq 0.05)$. The positive relationship between IV and PUFA was registered, $r$ was +0.983 . The strong positive relationship between TPC and $\mathrm{AC}$ as $1 / \mathrm{EC}_{50} \mathrm{DPPH}$ was observed, $r$ was +0.831 . On the other hand, $1 /$ $\mathrm{EC}_{50}{ }_{\mathrm{DPPH}}$ showed a positive moderate correlation with TTC, r was +0.768 . These results suggest that TPC and TTC are good predictors of in vitro antioxidant capacity. It can be concluded that the VOO obtained from the 'Roghiani' cultivar in Gharyan is highly comparable to the international varieties in its quality and for the enhancement of human health.

\section{ACKNOWLEDGMENTS}

Esalami would like to thank the Ministry of Higher Education in Libya for his PhD grant.

\section{CONFLICT OF INTEREST}

The author declare that are no conflicts of interest.

\section{REFERENCES}

Arabshahi-Delouee S, Urooj A. 2007. Antioxidant properties of various solvent extracts of mulberry (Morus indica L.) leaves. Food Chem. 102, 1233-1240. https://doi. org/10.1016/j.foodchem.2006.07.013

Ballus CA, Meinhart AD, de Souza Campos FA, da Silva LFDO, de Oliveira AF, Godoy HT. 2014. A quantitative study on the phenolic compound, tocopherol and fatty acid contents of monovarietal virgin olive oils produced in the southeast region of Brazil. Food Res. Int. 62, 74-83. https://doi.org/10.1016/j.foodres.2014.02.040

Bendini A, Cerretani L, Carrasco-Pancorbo A, Gómez-Caravaca AM, Segura-Carretero A, Fernández-Gutiérrez A, Lercker G. 2007. Phenolic molecules in virgin olive oils: a survey of their sensory properties, health effects, antioxidant activity and analytical methods. An overview of the last decade Alessandra. Molecules 12, 1679-1719. https://doi. org/10.3390/12081679

Ben Othman N, Roblain D, Thonart P, Hamdi M. 2008. Tunisian table olive phenolic compounds and their antioxidant capacity. J. Food Sci. 73, 235-340. https://doi. org/10.1111/j.1750-3841.2008.00711.x

Boggia R, Evangelisti F, Rossi N, Salvadeo P, Zunin P. 2005. Chemical composition of olive oils of the cultivar Colombaia. Grasas Aceites 56, 276-283. https://doi. org/10.3989/gya.2005.v56.i4.93

Boskou D. 1996. Olive Oil. Chemistry and Technology. AOCS Press, Champaign. IL. pp, 52-83. https://doi.org/10.1002/ food.19970410219

Brahmi F, Mechri B, Dabbou S, Dhibi M, Hammami M. 2012. The efficacy of phenolics compounds with different polarities as antioxidants from olive leaves depending on seasonal variations. Ind. Crops Prod. 38, 146-152. https://doi. org/10.1016/j.indcrop.2012.01.023
Caponio F, Alloggio V, Gomes T. 1999. Phenolic compounds of virgin olive oil: influence of paste preparation techniques. Food Chem. 64, 203-209. https://doi.org/10.1016/ s0308-8146(98)00146-0

Carpenter A. P. 1979. Determination of tocopherols in vegetable oils. J. Am. Oil Chem. Soc. 56, 668-671. https://doi. org/10.1007/bf02660070

Chtourou M, Gargouri B, Jaber H, Abdelhedi R, Bouaziz M. 2013. Comparative study of olive oil quality from Chemlali Sfax versus Arbequina cultivated in Tunisia. Eur. J. Lipid Sci. Technol. 115, 631-640. https://doi.org/10.1002/ejlt. 201200234

Dabbou S, Rjiba I, Nakbi A, Gazzah N, Issaoui M, Hammami, M. 2010. Compositional quality of virgin olive oils from cultivars introduced in Tunisian arid zones in comparison to Chemlali cultivars. Scientia Horticulturae 124, 122-127. https://doi.org/10.1016/j.scienta.2009.12.017

Dabbou S, Brahmi F, Dabbou S, Issaoui M, Sifi S, Hammami M. 2011. Antioxidant capacity of Tunisian virgin olive oils from different olive cultivars. Afr. J. Food Sci. Technol. 2, 92-97.

Del Coco L, Perri E, Cesari G, Muzzalupo I, Zelasco S, Simeone V, Schena FP, Fanizzi FP. 2013. NMR-based metabolomic approach for EVOO from secular olive trees of Apulia region. Eur. J. Lipid Sci. Technol. 115, 1043-1052. https:// doi.org/10.1002/ejlt.201300160

Elbeydi KR, Hamuda MA. 2016. Estimating price and income elasticity of olive oil demand in Libya during. Afaq. Eqtisadiah. J. 4, 5-16.

Fitó M, Covas MI, Lamuela-Raventós RM, Vila J, Torrents J, de la Torre C, Marrugat J. 2000. Protective effect of olive oil and its phenolic compounds against low density lipoprotein oxidation. Lipids 35, 633-638. https://doi.org/10.1007/ s11745-000-0567-1

Gouvinhas I, Machado J, Gomes S, Lopes J, Martins-Lopes P, Barros AI. 2014. Phenolic composition and antioxidant activity of monovarietal and commercial Portuguese olive oils. J. Am. Oil Chem. Soc. 91, 1197-1203. https://doi. org/10.1007/s11746-014-2462-x

Haiyan Z, Bedgood DR, Bishop AG, Prenzler PD, Robards K. 2007. Endogenous biophenol, fatty acid and volatile profiles of selected oils. Food Chem. 100, 1544-1551. https:// doi.org/10.1016/j.foodchem.2005.12.039

International Olive Oil Council (IOOC). 1984. International trade standards applying to olive oils and olive- residue oils. COI/T. $15 / \mathrm{NC}$ no 1 , Madrid, Spain.

ISO. International organization for Standardization. 2000. ISO 5509: 2000, Method of preparation of methyl-ester fatty acids. Geneva, Switzerland. https://doi.org/10.1515/ ci. 2000.22 .6 .167

ISO. International Organization for Standardization. 1990. ISO 5508: 1990, Animal and vegetable fats and oils-Analysis by gas chromatography of methyl esters of fatty acids. Geneva, Switzerland. https://doi.org/10.3403/00579002u

Krichène D, Allalout A, Salvador M. D, Fregapane G, Zarrouk M. 2010. Fatty acids, volatiles, sterols and triterpenic alcohols of six monovarietal Tunisian virgin olive oils. Eur. J. Lipid Sci. Technol. 112, 400-409. https://doi.org/10.1002/ ejlt.200900095

Krishnamurthy R, Kellens M. 1996. Fractionation and winterization, In Baileys industrial oil and fat products. Ed. Y. H. Hui. Fifth Edition, Vol. 4. John Wiley \& Sons, New York. 324.

Martínez ML, Maestri DM. 2008. Oil chemical variation in walnut (Juglans regia L.) genotypes grown in Argentina. Eur. J. Lipid Sci. Technol. 110, 1183-1189. https://doi.org/10.1002/ ejlt.200800121

Matthäus B, Özcan MM. 2011. Determination of fatty acid, tocopherol, sterol contents and 1,2-and 1, 3-diacylglycerols in four different virgin olive oil. J. Food Process Technol. 2, 1-4. https://doi.org/10.4172/2157-7110.1000117

Monasterio P, Ángeles Fernández M, Silva MF. 2013. Highthroughput determination of phenolic compounds in virgin olive oil using dispersive liquid-liquid microextractioncapillary zone electrophoresis. Electrophoresis 34, 18361843. https://doi.org/10.1002/elps.201300117 
Nakbi A, Issaoui M, Dabbou S, Koubaa N, Echbili A, Hammami M. Attia N. 2010. Evaluation of antioxidant activities of phenolic compounds from two extra virgin olive oils. J. Food Composition Analysis 23, 711-715. https://doi.org/10.1016/j.jfca.2010.05.003

Orčić D, Francišković M, Bekvalac K, Svirčev E, Beara I, Lesjak M, Mimica-Dukić N. 2014. Quantitative determination of plant phenolics in Urtica dioica extracts by high-performance liquid chromatography coupled with tandem mass spectrometric detection. Food Chem. 15, 48-53. https://doi.org/10.1016/j.foodchem.2013.07.097
Paquot C, Mercier J, Lefort D, Mathieu A, Perron R. 1967. Les Methodes analitiques des lipides simples (in Serbian). Poslovno udruženje proizvođača biljnih ulja. Beograd. pp, 175-179. https://doi.org/10.1021/ja00890a063

Wiesman Z. 2009. Desert olive oil cultivation. Advanced bio technologies. Academic Press. https://doi.org/10.1016/ b978-0-12-374257-5.00014-2

Yousfi K, Cert RM, García JM. 2006. Changes in quality and phenolic compounds of virgin olive oils during objectively described fruit maturation. Eur. Food Res. Technol. 223, 117-124. https://doi.org/10.1007/s00217-005-0160-5 